\title{
MULTICULTURALISM, MUSLIMS AND CITIZENSHIP: A THEORETICAL DEBATE
}

\author{
Qurat ul Aein Fozia*
}

\begin{abstract}
Over the last few decades, the term 'multiculturalism' has been in debate. This is not only because of issues surrounding cultural diversity, racism, or 'the minority versus the majority', but also because of religious differences, especially regarding Muslims in the West. Many queries have been raised about the inclusion of Muslims in European society as they seem to be barbaric and alien, especially after the events of $9 / 11$ in the USA and $7 / 7$ in London. This paper discusses the various complex debates surrounding the term 'multiculturalism' in the work of political philosophers like Tariq Modood, Bhikhu Parekh, Will Kymlicka, and others. It first introduces the term 'multiculturalism' as interpreted by different scholars and discusses the reasons for its current retreat. Multiculturalism is said to be challenging for religious groups, especially Muslims, because of its incompatibility with liberalism, considered to be the key element of Western civilisation. Therefore, this paper attempts to describe multiculturalism's relationship with citizenship and the long-term effect of national identity on civil society. It also discusses some basic concepts, like equality and dialogue, in relation to multiculturalism and tries to bring out the differences between liberal equality and the equality experienced under multiculturalism. This paper concludes with some policy recommendations for the adjustment of illiberal minorities (Muslims) within liberal societies (Europe) in the present world of super-diversity.
\end{abstract}

Keywords: multiculturalism, citizenship, dialogue, equality, politics of recognition.

\section{Introduction}

Since 2010, there has been a dramatic increase in the Muslim population of Europe, especially in the wake of a large influx of refugees and asylum seekers. ${ }^{1}$ Unfortunately, these Muslims have not always welcome, being frequently considered a potential threat, fueling Islamophobia on the one hand and radicalisation on the other. So, there arises a profound question about the integration of Muslims into secular liberal European nations, with one of the factors being their supposed incompatibility with Western liberal culture. ${ }^{2}$ 
Racism in the West has been variously defined by colour (1950-1960s), race (1960-1980s), ethnicity (1990s), and finally religion. Muslims in the West have been struggling with issues of integration and cultural pluralism since the 1960s. ${ }^{3}$ How to maintain their original identity in a secular European nation state has proven to be a big question. Muslims are considered disloyal for being illiberal and not good citizens because of their isolationism. Bhikhu Parekh rightly points out four European anxieties about Muslims being undemocratic, non-secular, illiberal, and multiculturalist. ${ }^{4}$

Multiculturalism is beneficial to Muslims for many reasons. First, it helps them to prove themselves loyal to the state. Second, it keeps in check detrimental government policies designed to maintain peace and harmony. ${ }^{5}$ Finally, it can be used to critique rightwing radical populist parties. ${ }^{6}$ Therefore, multiculturalism can be understood on three levels: political, policy action, and criticism. ${ }^{7}$ Accordingly, this paper is divided into three main sections. The first gives a brief, vivid picture of Muslims under multiculturalism; the second deals with its criticism; the third with multicultural citizenship and its associated concepts (equality, dialogue, national identity, the politics of recognition). The paper then concludes with some reflections on the problem, followed by policy recommendations which I believe need to be implemented at a global level for ultimate global peace.

\section{Multiculturalism}

Multiculturalism evolved from anti-racism. It is not a vague idea, but one wellgrounded in European socio-political realities. ${ }^{8}$ In the United States, the term has been used to discuss racism in newspapers, seminars, and other arenas ${ }^{9}$ since $2004 .{ }^{10}$ In the early 1960s and 1970s, the study of multiculturalism was discipline orientated, focusing on issues like economics, politics, sociology, and cultural studies. By the 1980s, however, the central focus was the integration of labour migrants; by the 1990s "changing immigration policies" (including increasing numbers of refugees) and "family reunification" were also added. ${ }^{11}$ Like culture, the term 'multiculturalism' is very unclear, ${ }^{12}$ meaning different things to different people, making it difficult to engage in practical considerations and policy orientation. ${ }^{13}$

Multiculturalism has become a topic of debate for all "political theorists, social theorists, sociologists, political scientists and educationists." 14 The study of multiculturalism is done in the following two ways. First, by means of political theory, with a focus on group identity, where the role of individual rights in liberalism manifests the Western nation state. Second, by means of policy studies, with a focus on group interactions and the policies that emerge to administer 
Western nations. Sometimes, tensions and conflict might develop when the above two overlap, such as with the Salman Rushdie controversy (The Satanic Verses), the murder of the filmmaker Theo van Gogh in the Netherlands, and the Danish Cartoon controversy. Also, there is much controversy between individual and group rights, such as when Sikhs are given special rights to wear turbans instead of motorcycle helmets. According to Rattansi, such traditional cultural practices should not be allowed to overrule essential individual rights and vice-versa. ${ }^{15}$ Therefore, the issues raised include: group representation and rights, the rights and status of immigrants, the recognition of minority nations, and the status of new social movements. ${ }^{16}$

In 2000, Parekh reviewed the key ideas shaping multiculturalism and came out emphatically in support of a pluralistic perspective of cultural diversity. ${ }^{17}$ For him, multiculturalism is about valuing cultural diversity, which makes us understand not just our own culture, but that of others as well. ${ }^{18}$ Brian Barry also defines multiculturalism as a project or discourse dealing with multiculturality, and which aims at the acceptance of cultural diversity ${ }^{19}$ Charles Taylor uses multiculturalism in two areas: to help recognise diversity and in contrast to interculturalism. ${ }^{20}$ For Tariq Modood, multiculturalism is a political idea developed to deal with the politics of democracy, from racism to negative difference to accepting the marginalised. It is a mode of group-based integration in the public sphere. He agrees that "political multiculturalism" might have been part of (or emerged from) "moral or truth relativism, liberalism, post-colonialism, (anti-)globalization," and so on, although it was based on, "the ideas of 'difference', 'multi' and a double concept of equality." ${ }^{21}$ However, he disagrees with Thompson's reference to "multi" as referring to separate groups, believing that there should be many groups that, although more or less distinct, conform to Wittgenstein's concept of "family resemblance." 22 The "multi" aspect of multiculturalism also applies to various types of racism, the most significant being cultural racism, present today as anti-Muslim racism (Islamophobia). ${ }^{23}$ However, the real multicultural challenge starts when people of particular regions enjoy normal citizenship while eliminating others from such a status on cultural grounds. ${ }^{24}$

Modood says that it is better to derive the concept of multicultural politics from "postwar extra-Europe/non-white immigration, their settlement and struggles and the policy responses" to their attaining equal cultural membership..$^{25}$ Multiculturalism can also be explored through a dynamic "social psychological approach," using tools developed by social psychology. The social-psychological approach helps to develop a sense of belonging via an accumulation of knowledge through communication with the 'other. ${ }^{26}$ 


\section{Multiculturalism and Muslims}

In the ongoing multiculturalism debate, religion has been neglected, ${ }^{27}$ perhaps because it is difficult to measure multiculturalism in terms of this concept. The exception is a Canadian study on atheism. Conducted by Steven Tomlins, this indicated that the ideology of multiculturalism has created a sense of inclusion across difference. Multiculturalism, therefore, may have an important role in managing diversity in the public sphere. ${ }^{28} \mathrm{~A}$ study by Beyer, however, found that, although approaches to multiculturalism are positive, practice is sometimes lacking. Canada is a good example of this. ${ }^{29}$ Certainly, Western liberal societies often exclude Muslims from the multiculturalism debate because of apprehension about identity politics. Also, some multiculturalists (including Will Kymlicka) say that multiculturalism deals only with cultural groups, not religious ones. According to Modood, however, not considering Muslims as a cultural group is a "secularist bias" and "ignorance-cum-prejudice." ${ }^{30}$ It has been an excuse for Europeans to exclude Muslims from the public sphere.

Nevertheless, a shift in focus from culture to religion has occurred post-9/11, when emphasis moved to Islamisation, ${ }^{31}$ civil society, citizenship, politics, identity, and liberalism. ${ }^{32}$ As a result, Islamic religious symbols (minarets/burqas) were contrasted with liberal values like freedom, leading to Islamophobia. However, this shift did not eliminate pre-existing forms of racism. Rather, these expanded, generating new forms of racism further reinforced by Eurocentric approaches. ${ }^{33}$

Muslims are an important subject of discussion under multiculturalism for two reasons: they are immigrants to Europe and their identity is the most contentious therein. In Britain, Muslims are in the multiculturalism debate for two reasons: their perceived illiberal cultural practices (FGM, veiling, hudud, etc.) and their association with terrorist events. Therefore, Muslim isolation is driven by their cultural practices (especially clitoridectomy), which again poses a "secularist bias" according to Modood. ${ }^{34}$ No one can choose to be born into a Muslim family, just as no one can choose to be of a particular race. This is the claim of multiculturalism, which goes against liberal citizenship. ${ }^{35}$ Muslims should not be blamed for being Muslim.

Many 'cultural Muslims' also come under the banner of multiculturalism due to their ethnicity (attached to Islam), not because of their adherence to Islam. They are only Muslim by birth. ${ }^{36}$ So, minority rights problems are not necessarily due to religion, but a postcolonial political strategy. ${ }^{37}$ Within this context, Western Muslims are considered to be a 'fifth column,' an enemy within intent on establishing an Islamic state. ${ }^{38}$ As a result, Islam and Muslims are repeatedly blamed and targeted. For example, the hijab is prohibited in France and minarets are not allowed in Switzerland ${ }^{39}$ Modood observes that a theory of 
multiculturalism is needed which brings ethnicity and religion together, without any anti-immigrant bias. Speaking about immigrant rights, Modood argues that multiculturalism should centre post-immigration groups within a social construct on Western soil. ${ }^{40}$ In contrast, Spinner Halev is of the opinion that any special treatment of religion, including exemption from specific laws, endorses inequality. ${ }^{41}$

\section{Multiculturalism and Its Criticism (Backlash/Retreat)}

In Europe, multiculturalism has gained a lot of criticism not only from rightwing 'conservative nationalists,' but also from leftists who say multiculturalist policies have failed to tackle racism. ${ }^{42}$ Certainly, multiculturalism is still unevenly developed in Western Europe and has seen backlash over the early twenty-first century. ${ }^{43}$ Angela Merkel, David Cameron, and Nicolas Sarkozy, for example, all acknowledged the end of multiculturalism during this period, ${ }^{44}$ with Merkel claiming "multiculturalism has utterly failed" in October 2010. Cameron likewise joined the debate in 2011, claiming "state multiculturalism" was the root cause of terrorism, leading to parallel lives and segregation. It should therefore be replaced with a "muscular liberalism." While similarly criticising multiculturalism, Sarkozy said that the French had been too worried about the identities of individuals entering the country and not enough with that of France itself. ${ }^{45}$ The current French president, Emmanuel Macron, has also shown resistance to multiculturalism. ${ }^{46}$ Trevor Phillips, former chairman of Britain's Commission for Racial Equality, warned that the UK was in danger of "sleepwalking" its way into segregation, blaming multiculturalism for this. ${ }^{47}$ The main criticism of multiculturalism, therefore, has been its 'ghettoisation' of communities and, hence, their 'parallelisation. ${ }^{48}$ Ted Cantle (a British community organiser) also sees multiculturalism as a generator of racism for these reasons. ${ }^{49}$ Abdul Bari, however, the Secretary General of the Muslim Council of Britain, rejects all this criticism, affirming the successful integration of British Muslims via multiculturalism. ${ }^{50}$

Criticism of multiculturalism is linked to the post-9/11 rise in Islamophobia. ${ }^{51}$ Heavily criticised for encouraging the social alienation of different groups, multiculturalism became an important issue after the terrorist attacks in London and the Netherlands. ${ }^{52}$ Mohammed B., for example, the murderer of Theo van Gogh, became a Dutch symbol for the weakness and unsuccessful nature of multiculturalism..$^{53}$ Multiculturalism therefore became an issue of growing concern; ${ }^{54}$ Mark Steyn of the UK's Daily Telegraph, following Phillips, identified multiculturalism as the real suicide bomber. ${ }^{55}$ 
Islamists have also attacked multiculturalism. As absolutists, they prefer to divide people into Muslims and non-Muslims, ${ }^{56}$ while showing resistance towards Western values. ${ }^{57}$ Islamist organisations like Hizb ul-Tahrir, for example, consider multiculturalism harmful to Muslims as it deteriorates their faith. ${ }^{58}$ However, Francis Fukyama says that multiculturalist policies shelter fanaticism in countries like Holland and Britain and need to be reversed. ${ }^{59}$

In the 1980s, far right groups criticised multiculturalism for providing immigrants with special privileges, thereby undermining the dominant social group. ${ }^{60}$ Even before 9/11 and 7/7, observes Modood, Muslim immigrants were considered "politically exceptional, culturally unreasonable and theologically alien." According to Gilles Kepel:

the $7 / 7$ bombers in London were the children of Britain's own multicultural society and that multiculturalism regards what differentiates religious and ethnic communities as essential, and sees... what unifies citizens of the same society-beyond race or faith [as] of secondary importance. ${ }^{61}$

Apart from the rightwing, anti-racists have also criticised multiculturalism. ${ }^{62}$ The UK's Commission for Racial Equality, for example, published an article by Kenan Malik arguing that multiculturalism is worse for segregating people than racism. A leading UK liberal columnist writing for The Guardian, the late Hugo Young, interpreted multiculturalism as "a useful bible" for Muslims whose sense of jihad overrules their civic values of tolerance, justice, and democracy. Farrukh Dhondy, an Asian one-time Black Panther, even considered it a fifth column that needs to be eradicated and replaced with "values of freedom and democracy." 63 It has also been criticised for its imprecision, making discussion about it and its policy orientation more difficult. ${ }^{64}$ It has been considered 'chameleon-like' and often contradictory. ${ }^{65}$ Also, multiculturalism has been unable to combat white oppression, which still remains unresolved. ${ }^{66}$

Ali Rattansi, however, argues that most public opposition to multiculturalism is either misguided or exaggerated. It is actually caused by what he terms a "triple transition," becoming the "container receiving anxieties" rooted in social and economic changes that are broader than immigration or multiculturalism. ${ }^{67}$

\section{Multiculturalism and Citizenship}

Many agree that a justifiable theory of citizenship capable of catering to the needs of diversity has yet to be developed by multiculturalists. ${ }^{68} \mathrm{~A}$ theory of common identity should, however, be brought forth if multiculturalism is to 
persist. So far, multiculturalists have put forward the concept of 'multicultural citizenship' as a common denominator between minority and majority groups. ${ }^{69}$ The concept of multicultural citizenship is ambiguous and complicated, however, being designed to counter de-ethnicisation in those liberal states that advocate minority rights. Iris Young (1989) calls such citizenship "universal citizenship," by which she means equal membership of liberal-democratic nation states in terms of rights..$^{70}$

Modood also refers to multicultural citizenship. ${ }^{71}$ As he notes, this concept emerged as a novel political idea, a new '-ism', in the context of "liberal or social democratic egalitarianism and citizenship." 72 Democratic citizenship possesses four indicators: peace and individual security, democracy, individual freedom, and inter-group equality. ${ }^{73}$ In consequence, Modood sees political multiculturalism as "democratic citizenship and belonging," unlike Parekh and Taylor, who put it in a broader philosophical perspective. ${ }^{74}$ By citizenship, Modood means the development of an inter-person relationship within the domain of an ethical and legal framework. Citizenship is like the flesh on the skeleton of the law. Key ideas like "liberty, equality, fraternity or unity and democracy" form the ethical framework of citizenship. The difference between liberal citizenship and multicultural citizenship, however, is that the former is based on the rights individuals have against the state, while the latter is supplemented by a horizontal relationship between citizens and the ethics of how we deal with each other as citizens ${ }^{75}$ (the ethics of inclusion). ${ }^{76}$ It means multicultural citizenship works on the Qur'anic principle of husn-i-akhlaq (good character).

Multiculturalist citizenship also means striving for a civil society. For illustration, Modood points to the Canadian Multiculturalism Act (1988), which ensures all society members publicly work for the preservation of their own culture. He also gives the example of CMEB (Commission for Multi-Ethnic Britain), also known as the Parekh Report, which highlights the necessity of going beyond the concept of liberal citizenship, something which is unachievable until the citizens of Britain fully engage with what it means to be British. ${ }^{77}$

Multicultural citizenship ultimately focuses on the individual rights of citizens and admits the fact that these rights are not the same for everyone, rather revolving around the identity of specific individuals. Such citizenship should not be limited to "legal rights, passports and the franchise" but be broadened in a "plural, dispersed and a dialogical way." According to Modood, radical secularism is a potential threat to current theories of multicultural citizenship, especially in Western Europe and especially for Muslims. Religious fundamentalism, domestic terrorism, and political opposition also put obstacles in the way of multicultural citizenship. ${ }^{78}$ Therefore, going beyond extremism and striving for peace is the key to keep multiculturalism alive. 
Kymlicka also speaks about multicultural citizenship and the rights of minorities, yet is biased against religious minorities. Modood's version of multiculturalism, meanwhile, is essentialised by its critics as group-based. ${ }^{79}$ As a key political philosopher, Modood has done a commendable job of making multicultural citizenship relevant to Anglophone political theory, ${ }^{80}$ proposing the concept of "differentiated citizenship" to assimilate different groups in society ${ }^{81}$ If the question of citizenship is controversial in traditional nation states, it becomes even more so in multi-nation states, where citizenship has to be modified to accommodate "sub-state national groups." In multi-nation states, federalism is employed, allowing minority groups that form a local majority to establish selfgovernance. ${ }^{82}$

\section{The Concept of 'Dialogue' and 'Equality'}

All multiculturalists argue for the importance of dialogue in cultural practice, both philosophically and politically. They give it a central place in the liberal nationalist/human rights/class-based approaches interculturalist critics of multiculturalism miss. ${ }^{83}$ Therefore, for the smooth functioning of multicultural society, there is dire need for dialogue "in conformity [to] familiar Habermasian principles grounded in love and emotional bonding for the community." ${ }^{84}$ Modood, Taylor, and Parekh all consider dialogue essential for multiculturalism. ${ }^{85}$ This dialogue should be reflected in every sphere of a multicultural society, whether political, economic, or cultural. This will allow the sharing of experience within the community. The dialogical approach makes us realise we are "ontologically related to one another" and not merely independent individuals. This helps us improve relations with the so called 'other." ${ }^{86}$

Multicultural citizenship is focused not merely on minorities, but the whole of society in order to express belonging based on equality. ${ }^{87}$ Liberal conceptions of equality entail two forms of person: citizens and those associated with them. According to multiculturalism, this is inequality within equality; citizenship should entail a right to be different, both in the private and public spheres. So, unlike classical liberalism, multiculturalism talks about two kinds of equality. ${ }^{88}$ First is the liberal concept of equality (which is gender and colour blind) and second is the acceptance of group self-identity. This kind of citizenship is not about who is to be recognised, but about conversations and re-negotiations. Multicultural citizenship is, thus, based on respect for all citizens, particularly those who are racially excluded, culturally denounced, and religiously sidelined ${ }^{89}$ Multiculturalism as a mode of integration, ensuring equality within difference and the inclusion of the marginalised. 
Based on the concept of "equal respect," ${ }^{90}$ Modood gives two protectionist statements and two positive statements about minorities in relation to the majority in a multicultural relationship: their protection from racism and prejudice, different modes of integration (including assimilation), their accommodation within shared public institutions, and their claim to multicultural citizenship (national identity). ${ }^{91}$

\section{National Identity}

Arguably, although multiculturalists have begun to develop a theory of citizenship, they have failed to develop a strong national identity. ${ }^{92}$ Modood, however, disputes this, noting that multicultural citizenship is very critical of cultural assimilation and liberal individualism, both of which undermine group identity. ${ }^{93}$ Although multicultural citizenship speaks for individual equality, it is not opposed to national identity. Rather, it works on the assumption that every citizen has their own individuality within their national group. This leads to pluralism, with each individual within a group having the right to maintain their identity. Under multiculturalism, the process of accommodation competes with a sense of nationality on two levels: with regards to a sense of belonging/loyalty (citizenship to the country) and in maintaining a sense of origin/diasporic identity. Hyphenated identities like Jewish-American or British-Muslim, therefore, are not necessarily an oxymoron. ${ }^{94}$ A multicultural society calls for unity within diversity, based on a common national identity and citizenship. This is possible within the context of Parekh's understanding of culture, as he believes national identity is embedded in a society's political culture. However, Modood denies this restrictive meaning of national identity because, questioning the separation of politics and culture advocated by Parekh and the latter's positioning of national identity within a political rather than cultural gamut. ${ }^{95}$

Kymlicka advocates self-rule for all nations (self-determination for immigrants), while Parekh believes that national identities need not be linked to nationalism because political communities can be trans-national. According to him, differing values, customs, and traditions should lead to intercultural learning, regardless of differences in nationality. ${ }^{96}$ In sum, Modood suggests that a "Multicultural Nationalism," or series of hyphenated identities that nevertheless remain aligned to a specific national identity, offer a feasible solution to present-day crises. ${ }^{97}$

\section{The Politics of Recognition}

Multiculturalism is a polysemous term related to identity politics, the politics of difference, and the politics of recognition. ${ }^{98}$ According to Modood, these diversities should not be eliminated, but recognised. Identity politics is in no way 
opposite to citizenship, which is rather enriched by a civic sense of individual belonging. ${ }^{99}$ Modood says that Taylor's conceptualisation of the politics of recognition based on equal respect is the basic idea behind multiculturalism. ${ }^{100}$ According to Taylor, our identities are dialogically linked to each other because, socially, humans are interdependent. The politics of recognition works on two levels: the intimate sphere, where the formation of self takes place in dialogue with others, and the public sphere, where "the politics of equal recognition" plays a dramatic role. Thus, the journey from "politics of identity" to "politics of universalism" ends when the distinction between different classes of people stops and "the politics of dignity" comes into being, reinforced by "the politics of difference," which means every individual is respected and honoured for their uniqueness. Dialogue also imparts a central importance to the "politics of recognition," which, if denied, damages the democratic ethos of society. Restraining such recognition therefore leads to oppression. ${ }^{101}$

\section{Reflections}

All of the abovementioned scholars have their own way of understanding multiculturalism. ${ }^{102}$ While Tahir Abbas states that the question of multicultural citizenship for Muslims need not be political, Abbas wants (British) Muslims to live as obedient minorities in non-Muslim settings and participate in the public sphere. Ultimately, new ways of integration should be discovered to protect Muslim minorities from isolationism and ensure their full participation in Western society, while keeping their identities intact. ${ }^{103}$ Arguably, however, the question is not about integration, but the fear which developed after 9/11 and 7/7. Multiculturalism could combat Islamophobia, a cultural racism in Britain and other places. It could also help maintain and preserve the ethno-religious identities of Muslims. It is therefore termed "civic rebalancing" instead of "retreat" by Modood and Nasr. ${ }^{104}$

Radical/ideological (American liberal/French republican) secularism is the biggest challenge facing multiculturalism. Modood offers an accommodative (moderate or inclusive) model of secularism, one which respects religion beyond mere toleration and could lead to egalitarian and democratic citizenship. ${ }^{105}$ While a crisis in laïcité, or the concept of secularism in France, has prompted Emmanuel Macron to argue that à la Française needs to be reformed, I argue that multiculturalism should become the policy of contemporary multi-ethnic and multi-religious France. Instead of interfering in religion and trying to reform Islam, the French government needs to prioritise social inclusion, political participation, and the economic development of religious minorities. ${ }^{106}$ 
Multiculturalism demands that different ethnic groups be treated equally because, as best explained by I. M. Young, its goal is identity consciousness rather than identity blindness. ${ }^{107}$ As per Young, equality is not assimilation under a majority, but the positive self-definition of a minority. ${ }^{108}$ Identity politics, however, is currently considered a cancer that threatens to shatter the foundations of liberalism. ${ }^{109}$ Nevertheless, if Muslims are allowed to represent themselves in the political sphere, to bear the "family resemblance" discussed above, multiculturalism can be successful. ${ }^{110}$ While critics of multiculturalism see identity politics as a threat, as illiberal authoritarianism designed to overturn liberalism in the name of equality, there is also a more positive tussle between identity politics and liberalism, allowing Kymlicka to recognise "liberal multiculturalism" as a mid-point between the two. As he argues, core liberal values like freedom, equality, human rights etc. are part of multiculturalism, too.

\section{Conclusion}

Multiculturalism is understood differently by different people. ${ }^{111}$ Though it has received a lot of criticism, it remains a better option that either assimilation or integration. ${ }^{112,113}$ Most successful in Europe, the debate is now about how to employ the right political framework to support it. ${ }^{114}$ The official 2001 reports into the civil riots that gripped the northern English towns of Oldham and Burnley that same year demonstrated an appreciation for multiculturalism; they did not blame it for creating segregation/Balkanisation. Also, the related Bradford Race Review criticised the UK's National Curriculum for its failure to teach about different cultures and faiths in a diverse multicultural community. ${ }^{115}$ Therefore, those who consider contemporary Muslim identity issues as "an unwanted and illegal child of multiculturalism" are left with two options: either shun the concept of equality as identity recognition and go back to the liberal idea of equality (colour and gender-blind) or recognise that multicultural equality is impossible without a consideration of secularism. ${ }^{116}$

A combination of both classical liberalism and pluralism is appropriate for the inclusion of minority citizens in modern European societies. It will represent unity in diversity, both in the private and public spheres. For example, "a citizen based polity within the EU" rooted in Tariq Ramadan's "civic ethic" will not only allow Muslim integration but also greater Muslim contributions to society. ${ }^{117}$ Both society's majorities and minorities should have the freedom to fully celebrate their religious occasions through inclusivity. Muslims in Britain should not focus on de-Christianising Europe, but instead find new ways to successfully integrate. ${ }^{118}$ This will create an ethno-religious mix alongside democratic citizenship and 
individual rights, moving beyond toleration towards mutual understanding through a process of dialogue. ${ }^{119}$ But, while multiculturalism enjoys a strong position within the European Union, at least theoretically, much is still left to be done. ${ }^{120}$

This paper concludes with the following policy recommendations:

- Multicultural policies are not about racism; they challenge it. This should be recognised by all, whether on the political left or right.

- Minority rights should be given due consideration, regardless of whether they refer to settled ethnic groups or immigrants.

- European Muslims should contribute to the public sphere and be able to perform their religious duties without fear.

- Individual identities are important and should not be assimilated.

- While Europe should follow securitisation measures, it should not blame every violent act on multiculturalism.

- Liberal equality should be replaced by a "double concept of equality" so as to make law and faith concomitant.

- There should be institutional accommodation of Muslims in European countries, not a racialisation in terms of culture, politics, and terrorism.

\section{Notes}

* Qurat ul Aein is a Research Scholar at the Shah-i-Hamadan Institute of Islamic Studies, University of Kashmir, working on the theme, "Islam and Pluralism in modern Perspective, A Study of Contemporary Muslim Scholars" under the supervision of Prof. Naseem Ahmad Shah. Email: qurat029@gmail.com.

1. Conrad Hackett, '5 Facts About the Muslim Population in Europe,' Pew Research Center. Available at: https://www.pewresearch.org/fact-tank/2017/11/29/5facts. (Accessed on: 16 December 2020).

2. Bichara Khader, 'Muslims in Europe: The Construction of a "Problem", OpenMind BBVA. Available at: https://www.bbvaopenmind.com/en/articles/ muslims-in-europe-the-construction-of-a-problem/. (Accessed on: 17 December 2020).

3. Tahir Abbas, 'After 9/11: British South Asian Muslims, Islamophobia, Multiculturalism, and the State,' American Journal of Islamic Social Sciences 21, no. 3 (December, 2017): 26-38.

4. Bhikhu Parekh, 'Feeling at Home: Some Reflections on Muslims in Europe,' Harvard Middle Eastern and Islamic Review 8 (2009): 51-85. 
5. Shahram Akbarzadeh and Joshua M. Roose, 'Muslims, Multiculturalism and the Question of the Silent Majority,' Journal of Muslim Minority Affairs 3 (2011): 309-25.

6. Pieter Bevela and Raymond Taras, 'The Twilight of Multiculturalism? Findings from across Europe,' in Challenging Multiculturalism: European Models of Diversity, ed. Raymond Taras (Edinburgh: Edinburgh University Press, 2012), 3-24.

7. Marco Antonsich, 'Interculturalism versus Multiculturalism the Cantle-Modood Debate,' Ethnicities 4 (2016): 495-508.

8. Tariq Modood, Multiculturalism: A Civic Idea (Cambridge: Polity Press, 2007), 113-38.

9. Nathan Glazer, 'Multiculturalism and American Exceptionalism,' in Multicultural Questions, ed. Christian Joppke (New York: Oxford University Press, 1999), 183.

10. Tariq Modood, 'Remaking Multiculturalism After 7/7,' Financial Times, 1 January 2005.

11. Bevela and Taras, 'The Twilight of Multiculturalism?' 6-7.

12. Lisbeth Aggestam and Christopher Hill, 'The Challenge of Multiculturalism in European Foreign Policy,' International Affairs 84, no.1 (2008): 97-114.

13. Modood, 'Remaking Multiculturalism.'

14. Paul Kelly, 'Introduction: Between Culture and Equality,' in Multiculturalism Reconsidered: Culture and Equality and its Critics, ed. Paul Kelly (Cambridge: Polity Press, 2002), 114.

15. Ali Rattansi, Multiculturalism: A Very Short Introduction (Oxford: Oxford University Press, 2011), 2-3.

16. Kelly, 'Between Culture and Equality,' 1.

17. Bevela and Taras, 'The Twilight of Multiculturalism?' 8.

18. Tariq Modood, 'Their Liberalism and Our Multiculturalism?' The British Journal of Politics and International Relations 3, no. 2 (2001): 245-57.

19. Aggestam and Hill, 'The Challenge of Multiculturalism.'

20. Charles Taylor, 'Interculturalism or Multiculturalism?' Philosophy and Social Criticism 38, no. 4-5 (2012): 413-23.

21. Modood, Multiculturalism, 18, 56, 70.

22. Tariq Modood, 'Multiculturalism and Groups,' Social and Legal Studies 17, no. 4 (2008): 549-53.

23. Modood, 'Remaking Multiculturalism.' See also Modood, Multiculturalism, 41.

24. Taylor, 'Interculturalism or Multiculturalism?'

25. Modood, Multiculturalism, 37.

26. Caroline Howarth and Eleni Andreouli, "'Has Multiculturalism Failed ?" The Importance of Lay Knowledge and Everyday Practice,' Institute of Social Psychology Research Paper, The London School of Economics and Political Science Publications, (2012).

27. Modood, 'Their Liberalism and Our Multiculturalism?'

28. Lori G. Beaman, 'Religious Diversity in the Public Sphere: The Canadian Case,' Religions 8, no. 12 (2017): 1-18.

29. Ibid. 
30. H. A. Hellyer, Muslims of Europe: The "Other" Europeans (Edinburgh: Edinburgh University Press, 2011), 24-6.

31. Dorota A. Gozdecka et al., 'From Multiculturalism to Post-multiculturalism,' Journal of Sociology 50, no. 1 (2014): 51-64.

32. Abbas, 'After 9/11,' 26-38.

33. Gozdecka et al., 'From Multiculturalism,' 51-64.

34. Nasar Meer and Tariq Modood, 'The Multicultural State We're In: Muslims, "Multiculture" and the "Civic Re-Balancing," Political Studies 57, no. 3 (2009): 473-97.

35. Modood, Multiculturalism, 65.

36. Akbarzadeh and Roose, 'Muslims, Multiculturalism,' 309-25.

37. Will Kymlicka and Eva Pfostl, Multiculturalism and Minority Rights in the Arab World (Oxford: Oxford University Press, 2014) 110.

38. Akbarzadeh and Roose, 'Muslims, Multiculturalism.'

39. Chris Allen, 'Islamophobia and the Crises of Europe's Multiculturalism,' in New Multicultural Identities in Europe, ed. Erkan Toguslu et al. (Leuven: Leuven University Press, 2014).

40. Modood, Multiculturalism, 33, 36.

41. Modood, 'Their Liberalism and Our Multiculturalism?'

42. Allen, 'Islamophobia.'

43. Rattansi, Multiculturalism, 39.

44. Taylor, 'Interculturalism or Multiculturalism?'

45. Allen, 'Islamophobia.'

46. Gwenaelle Bauvois, "'France has never been and never will be a multicultural country" (Super)-diversity in Macron's France,' Siirtolaisuus-Migration 45, no.2 (2019): 8-10.

47. Rattansi, Multiculturalism, 75-6.

48. Gozdecka et al, 'From Multiculturalism.'

49. Christian Joppke, 'War of Words : Interculturalism v. Multiculturalism,' Comparative Migration Studies 6, no. 1 (2018): 245-58.

50. Akbarzadeh and Roose, 'Muslims, Multiculturalism.'

51. Kymlicka and Pfostl, Multiculturalism and Minority Rights, 104.

52. Aggestam and Hill, 'The Challenge of Multiculturalism.'

53. Rattansi, Multiculturalism, 90-1.

54. Aggestam and Hill, 'The Challenge of Multiculturalism.'

55. Rattansi, Multiculturalism, 76.

56. Modood, 'Remaking Multiculturalism.'

57. Enzo Colombo, 'Multiculturalisms: An Overview of Multicultural Debates in Western Societies,' Current Sociology 63, no. 6 (2015): 800-24.

58. Akbarzadeh and Roose, 'Muslims, Multiculturalism.'

59. Modood, Multiculturalism, 11.

60. Bevela and Taras, 'The Twilight of Multiculturalism?' 7.

61. Akbarzadeh and Roose, 'Muslims, Multiculturalism.'

62. Modood, 'Their Liberalism and Our Multiculturalism?'

63. Modood, Multiculturalism,10.

64. Ibid, 43.

65. Stephan H. Jones, 'The 'metropolis of dissent': Muslim Participation in 
Leicester and the "Failure" of Multiculturalism in Britain,' Ethnic and Racial Studies 38, no. 11 (2015): 1969-85.

66. Colins Imoh, 'How the Failure of Multiculturalism led to the Rise of Black Lives Matter,' The Conversation. Available at: https://theconversation.com/howthe-failure-of-multiculturalism-led-to-the-rise-of-black-lives-matter-144463. (Accessed on: 18 December 2020).

67. Rattansi, Multiculturalism, 4-5.

68. Modood, Multiculturalism, 144.

69. Hellyer, Muslims of Europe, 22-4.

70. Christian Joppke, 'Multicultural Citizenship: A Critique,' European Journal of Sociology 42, no. 2 (2020): 431-47.

71. Modood, 'Multiculturalism and Groups.'

72. Modood, Multiculturalism, 6 .

73. Will Kymlicka, 'Multicultural Citizenship within Multination States,' Ethnicities 11, no. 3 (2020): 281-302.

74. Modood, Multiculturalism, 61.

75. Antonsich, 'Interculturalism versus Multiculturalism.'

76. Beaman, 'Religious Diversity in the Public Sphere.'

77. Modood, Multiculturalism, 13-6.

78. Ibid., 128-55.

79. Christian Stokke and Lena Lybaek, 'Combining Intercultural Dialogue and Critical Multiculturalism,' Ethnicities 18, no. 1 (2018): 70-85.

80. Modood, Multiculturalism, 18.

81. Frederick Stjernfelt, 'Liberal Multiculturalism as Political Philosophy: Will Kymlicka,' The Monist 95, no. 1 (2012): 49-71.

82. Kymlicka, 'Multicultural Citizenship.'

83. Nasar Meer and Tariq Modood, 'How does Interculturalism contrast with Multiculturalism,' Journal of Intercultural Studies 33, no. 2 (2012): 175-96,

84. Catarina Kinnvall and Paul Nesbitt Larking, The Political Psychology of Globalisation (New York: Oxford University Press, 2011), 80.

85. Modood, 'Remaking Multiculturalism'; Modood, 'Multiculturalism and Groups.'

86. Kinnvall and Larking, 'The Political Psychology of Globalisation,' 84, 96.

87. Tariq Modood and John Salt, Global Migration, Ethnicity and Britishness (New York: Palgrave Macmillan, 2013), 46.

88. Antonsich, 'Interculturalism versus Multiculturalism.'

89. Modood, 'Multiculturalism and Groups,' 549-53.

90. Modood, 'Remaking Multiculturalism.'

91. Tariq Modood, 'Multiculturalism, Interculturalisms and the Majority,' in Multiculturalism and Interculturalism: Debating the Dividing Lines, ed. Nasar Meer, Tariq Modood and Ricard Zapata-Barrero (Edinburgh: Edinburgh University Press, 2016), 246-65.

92. Hellyer, Muslims of Europe, 24.

93. Modood, 'Multiculturalism and Groups.'

94. Modood, Multiculturalism, 45.

95. Modood, 'Their Liberalism and Our Multiculturalism?'

96. Varun Uberoi, 'National Identity: A Multiculturalist's Approach,' Critical 
Review of International Social and Political Philosophy 21, no. 1 (2018): 46-64.

97. Tariq Modood, 'Multicultural Nationalism,'openDemocracy. Available at: $\quad$ https://www.opendemocracy.net/en/can-europe-make-it/multiculturalnationalism/. (Accessed on: 19 December 2020).

98. Colombo, 'Multiculturalisms.'

99. Modood, Multiculturalism, 118, 36, 130.

100.Modood, 'Remaking Multiculturalism.'

101.Charles Taylor, Multiculturalism: Examining the Politics of Recognition (Princeton: Princeton University Press, 1994), 32-8.

102. Stokke and Lybaek, 'Combining Intercultural Dialogue': 70-85.

103. Abbas, 'After 9/11,' 26-38.

104.Nasar Meer, and Tariq Modood, 'Interculturalism, Multiculturalism, or Both?' Political Insight 3, no. 1 (2012): 30-3.

105.Tariq Modood, 'Moderate Secularism: A European Conception,' openDemocracy. Available at: http://www.opendemocracy.net/en/moderatesecularism-european-conception/. (Accessed on: 20 December 2020).

106. Andrew West, 'Is aggressive Secularism dividing France,' ABC The Religion and Ethics Report. Available at: https://www.abc.net.au/radionational/programs/ religionandethicsreport/is-aggressive-secularism-dividing-france/12916462. (Accessed on: 20 December 2020).

107.I.M Young, Justice and the Politics of Difference (Princeton: Princeton University Press, 1990).

108. Tariq Modood, 'Muslims and European Multiculturalism,' openDemocracy. Available at: https://www.opendemocracy.net/en/muslims-and-europeanmulticulturalism/. (Accessed on: 20 December 2020).

109.Zack Beauchamp, 'Identity Politics isn't hurting Liberalism. It's saving it,' Vox. Available at: https://www.vox.com/2020/2/20/20954059/liberalism-identitypolitics-defense. (Accessed on: 21 December 2020).

110. Tariq Modood, 'Identity, Muslims and Multiculturalism,' PLAINislam. Available at: http://www.plainislam.com/in-depth/identity-muslims-andmulticulturalism. (Accessed on: 21 December 2020).

111. Caroline and Andreouli, 'Has Multiculturalism Failed?'

112. Modood, 'Remaking Multiculturalism.'

113. Modood, Multiculturalism, 165.

114. Hellyer, Muslims of Europe, 51.

115. Rattansi, Multiculturalism, 73-5.

116. Modood, Multiculturalism, 66.

117. Hellyer, Muslims of Europe, 56-7.

118. Modood, 'Multiculturalism, Interculturalisms and the Majority.'

119. Modood, Multiculturalism, 8,60 .

120. Hellyer, Muslims of Europe, 179, 56.

\section{Bibliography}

Abbas, Tahir. 'After 9/11: British South Asian Muslims, Islamophobia, Multiculturalism, and the State.' American Journal of Islamic Social Sciences 
21, no. 3 (December, 2017): 26-38.

Aggestam, Lisbeth, and Christopher Hill. 'The Challenge of Multiculturalism in European Foreign Policy.' International Affairs 84, no.1 (2008): 97-114.

Akbarzadeh, Shahram, and Joshua M. Roose. 'Muslims, Multiculturalism and the Question of the Silent Majority.' Journal of Muslim Minority Affairs 3 (2011): 309-25.

Allen, Chris. 'Islamophobia and the Crises of Europe's Multiculturalism.' In New Multicultural Identities in Europe, edited by Erkan Toguslu et al., 213-28. Leuven: Leuven University Press, 2014.

Antonsich, Marco. 'Interculturalism versus Multiculturalism the Cantle-Modood Debate.' Ethnicities 4 (2016): 495-508.

Bauvois, Gwenaelle. "“France has never been and never will be a multicultural country” (Super)-diversity in Macron's France.' Siirtolaisuus-Migration 45, no. 2 (2019): 8-10.

Beaman, Lori G. 'Religious Diversity in the Public Sphere: The Canadian Case.' Religions 8, no. 12 (2017): 1-18.

Beauchamp, Zack. 'Identity Politics isn't hurting Liberalism. It's saving it,' Vox. Available at: https://www.vox.com/2020/2/20/20954059/liberalism-identitypolitics-defense.

Bevela, Pieter, and Raymond Taras. 'The Twilight of Multiculturalism? Findings from across Europe.' In Challenging Multiculturalism: European Models of Diversity, edited by Raymond Taras, 3-24. Edinburgh: Edinburgh University Press, 2012.

Colombo, Enzo. 'Multiculturalisms: An Overview of Multicultural Debates in Western Societies.' Current Sociology 63, no. 6 (2015): 800-824.

Glazer, Nathan. 'Multiculturalism and American Exceptionalism.' In Multicultural Questions, edited by Christian Joppke. (New York, Oxford University Press, 1999).

Gozdecka, Dorota A. et al. 'From Multiculturalism to Post-multiculturalism.' Journal of Sociology 50, no. 1 (2014): 51-64.

Hackett, Conrad. ' 5 Facts About the Muslim Population in Europe,' Pew Research Center. Available at: https://www.pewresearch.org/fact-tank/2017/11/29/5-facts.

Hellyer, H. A. Muslims of Europe: The “Other” Europeans. Edinburgh: Edinburgh University Press, 2011.

Howarth, Caroline, and Eleni Andreouli, “Has Multiculturalism Failed?" The Importance of Lay Knowledge and Everyday Practice.' Institute of Social Psychology Research Paper, The London School of Economics and Political Science Publications, 2012.

Imoh, Colins. 'How the Failure of Multiculturalism led to the Rise of Black Lives Matter.' The Conversation. Available at: https://theconversation.com/how-the- 
failure-of-multiculturalism-led-to-the-rise-of-black-lives-matter-144463.

Jones, Stephan H. 'The 'metropolis of dissent': Muslim Participation in Leicester and the "failure" of Multiculturalism in Britain.' Ethnic and Racial Studies 38, no. 11 (2015): 1969-85.

Joppke, Christian. 'Multicultural Citizenship: A Critique.' European Journal of Sociology 42, no. 2 (2020): 431-447.

Joppke, Christian. 'War of Words: Interculturalism v. Multiculturalism.' Comparative Migration Studies 6, no. 1 (2018): 245-258.

Kelly, Paul. 'Introduction: Between Culture and Equality.' In Multiculturalism Reconsidered: Culture and Equality and its Critics, edited by Paul Kelly, 1-17. Cambridge: Polity Press, 2002.

Khader, Bichara. 'Muslims in Europe: The Construction of a "Problem",' OpenMind $B B V A$. Available at: https://www.bbvaopenmind.com/en/articles/muslims-ineurope-the-construction-of-a-problem/.

Kinnvall Catarina, and Paul Nesbitt Larking. The Political Psychology of Globalisation. New York: Oxford University Press, 2011.

Kymlicka, Will. 'Multicultural Citizenship within Multination States.' Ethnicities 11, no. 3 (2020): 281-302.

Kymlicka, Will, and Eva Pfostl. Multiculturalism and Minority Rights in the Arab World. Oxford: Oxford University Press, 2014.

Meer, Nasar, and Tariq Modood, 'How does Interculturalism contrast with Multiculturalism.’ Journal of Intercultural Studies 33, no. 2 (2012): 175-196,

Meer, Nasar, and Tariq Modood, 'Interculturalism, Multiculturalism, or Both?' Political Insight 3, no.1 (2012): 30-33.

'The Multicultural State We're in: Muslims, "Multiculture" and the “Civic Re-Balancing."” Political Studies 57, no. 3 (2009): 473-497.

Modood, Tariq. 'Identity, Muslims and Multiculturalism,' PLAINislam. Available at: http://www.plainislam.com/in-depth/identity-muslims-and-multiculturalism.

'Moderate Secularism: A European Conception,' openDemocracy. Available at: http://www.opendemocracy.net/en/moderate-secularism-europeanconception/.

'Multicultural Nationalism,' openDemocracy. Available at: https:// www.opendemocracy.net/en/can-europe-make-it/multicultural-nationalism/.

'Multiculturalism, Interculturalisms and the Majority.' In Multiculturalism and Interculturalism: Debating the Dividing Lines, edited by Nasar Meer, Tariq Modood and Ricard Zapata-Barrero, 246-265. Edinburgh: Edinburgh University Press, 2016. (2008): 549-553.

'Multiculturalism and Groups.' Social and Legal Studies 17, no. 4 
Available · Muslims and European Multiculturalism,' openDemocracy.
at: https://www.opendemocracy.net/en/muslims-and-europeanmulticulturalism/.

2005 .

'Remaking Multiculturalism After 7/7.' Financial Times, 1 January

. 'Their Liberalism and Our Multiculturalism?' The British Journal of Politics and International Relations 3, no. 2 (2001): 245-257. . Multiculturalism: A Civic Idea. Cambridge: Polity Press, 2007.

Modood, Tariq, and John Salt. Global Migration, Ethnicity and Britishness. New York: Palgrave Macmillan, 2013.

Parekh, Bhikhu. 'Feeling at Home: Some Reflections on Muslims in Europe.' Harvard Middle Eastern and Islamic Review 8 (2009): 51-85.

Rattansi, Ali. Multiculturalism: A Very Short Introduction. Oxford: Oxford University Press, 2011.

Stjernfelt, Frederick. 'Liberal Multiculturalism as Political Philosophy: Will Kymlicka.' The Monist 95, no. 1 (2012): 49-71.

Stokke, Christian, and Lena Lybaek, 'Combining Intercultural Dialogue and Critical Multiculturalism.' Ethnicities 18, no.1 (2018): 70-85.

Taylor, Charles. 'Interculturalism or Multiculturalism?' Philosophy and Social Criticism 38, no. 4-5 (2012): 413-423.

Taylor, Charles. Multiculturalism: Examining the Politics of Recognition. Princeton: Princeton University Press, 1994.

Uberoi, Varun. 'National Identity: A Multiculturalist's Approach.' Critical Review of International Social and Political Philosophy 21, no. 1 (2018): 46-64.

West, Andrew. 'Is aggressive Secularism dividing France,' $A B C$ The Religion and Ethics Report. Available at: https://www.abc.net.au/radionational/programs/ religionandethicsreport/is-aggressive-secularism-dividing-france/12916462.

Young, I. M. Justice and the Politics of Difference. Princeton: Princeton University Press, 1990. 